\title{
Havayolu İşletmelerinde E-hizmet Kalitesi Boyutlarının Önem Düzeylerinin Belirlenmesi ${ }^{1}$
}

\begin{abstract}
Mahmut Bakır²
Özlem Atalık ${ }^{3}$

Havayolu İşletmelerinde E-hizmet Kalitesi Boyutlarının Önem Düzeylerinin Belirlenmesi

Öz

Bilgi teknolojilerinde yaşanan gelişmeler neticesinde ürünlerin dağıtımı internet üzerinden sağlanmaya başlanmış ve havayolu taşımacılığı sektörü de bu gelişmeden fazlasıyla etkilenmiştir. Bu kapsamda seyahat acentalarının sunduğu hizmetlerin payı giderek düşerken, internet kanalı başta düşük maliyetli taşıyıcılar olmak üzere havayolu işletmeleri tarafından yaygın bir şekilde kullanılmaya başlanmıştır. Bu çalışmada havayolu işletmelerinde sunulan e-hizmetlerde kaliteyi etkileyen unsurların önem düzeylerinin belirlenmesi amaçlanmıştır. Değerlendirme aşamasında AHP (Analitik Hiyerarşi Prosesi) yönteminin kullanıldığı bu çalışmada, e-hizmet kalitesi 3 ana kriter ve 13 alt kriterden oluşan hiyerarşik yapıyla ele alınmıştır. Çalışma sonucundan hizmet kalitesi en önemli ana kriter olarak belirlenirken güvenilirlik ve anlaşılabilirlik unsurlarının en önemli alt kriterler olduğu görülmüştür. Önem düzeyi en düşük kriter ise kişiselleş-

Determining the Importance Level of E-Service Quality Dimensions in Airline Companies

\section{Abstract}

Because of developments in information technology, distribution of products has started to be provided over the internet, and the airline industry has been affected too much by this situation. In this context, while the share of services offered by travel agencies has been gradually decreasing, the internet has started to be widely used by airline companies, especially by low-cost carriers. This study aims to determine the importance level of the factors affecting e-service quality provided in the airline industry. In this study, the AHP (Analytic Hierarchy Process) method is used in the evaluation phase. Eservice quality is evaluated by a hierarchical structure consisting of 4 main criteria and 13 sub-criteria. While service quality is determined as the most important main criterion, it is seen that reliability and understandability are found to be the most important sub-criteria. The most insignificant criterion also is personalization.
\end{abstract} tirme olarak belirlenmiştir.

Anahtar Kelimeler: Havayolu, E-hizmet Kalitesi, Analitik Hiyerarşi Prosesi
Keywords: Airline, E-service Quality, Analytical Hierarchy Process

\section{Giriş}

İnternet teknolojilerinde yaşanan gelişmeler ile birlikte dünya üzerinde büyük bir dönüşüm süreci yaşanmış ve bu durum birçok sektörü derinden etkilemiştir. Bu süreçte yaşanan gelişmelerden biri de internetin işletmeleri pazarlama aracı olarak desteklemeye başlamasıdır. Bu durumdan havayolu taşımacılığı sektörü en fazla etkilenen sektörlerden biri iken sektörel anlamda en büyük değişim ürünlerin üreticiden tüketiciye akışını ifade eden dağıtım işlevi üzerinde yaşanmıştır. Önceleri havayolu taşımacılığı sektöründe dağıtım telefon ve teletip

\footnotetext{
${ }^{1}$ Bu çalışma Anadolu Üniversitesi Sosyal Bilimler Enstitüsü Sivil Havacılık Yönetimi Anabilim Dalı'nda Doç. Dr. Özlem Atalık danışmanlı̆ında Mahmut Bakır tarafından "Havayolu İşletmelerinde E-hizmet Kalitesinin Değerlendirilmesine Yönelik Bütünleşik Bir Yaklaşım” ismiyle tamamlanarak 28.12.2017 tarihinde savunulan yüksek lisans tezinden türetilmiştir.

${ }^{2}$ Arş. Gör., Samsun Üniversitesi, Sivil Havacılık Yüksekokulu, Havacılık Yönetimi Bölümü, mahmut.bakir@omu.edu.tr, yazar ORCID Bilgisi: http://orcid.org/0000-0002-3898-4987.

${ }^{3}$ Doç Dr., Eskişehir Teknik Üniversitesi, Havacılık ve Uzay Bilimleri Fakültesi, Havacılık Yönetimi Bölümü, oatalik@anadolu.edu.tr, yazar ORCID Bilgisi: http://orcid.org/0000-0003-4249-2237.
} 
vasıtasıyla fiyat listeleri üzerinden yapılırken (Thakran ve Verma, 2013), 1960' yıllara gelinmesiyle birlikte CRS (Computer Reservation System) teknolojisi vasıtasıyla havayollarına ait terminallerin acentalara kurulmasıyla acentaların rolü giderek artmıştır. Sonraki süreçte 1990' Iı yıllarda internetin sivil amaçlı kullanıma açılmasıyla havayolları daha düşük maliyetli ve etkin hizmet sunabilmek için internet teknolojilerine yönelmişlerdir. Bu noktada internet siteleri dağıtım maliyetlerini düşürmek ve sektörel yapıyı şekillendirmek için büyük bir fırsat haline gelmiştir. Örneğin havayolu işletmelerinin dağıtım faaliyetlerinde yer alan aracıları saf dışı bırakması neticesinde seyahat maliyetlerinde \%12'lik bir azalma gerçekleşmiştir (Golden vd., 2003).

Günümüzde havayolu işletmeleri dağıtım faaliyetlerini birçok kanal üzerinden sürdürse de en büyük gelişim havayolu web siteleri üzerinde görülmüştür (Shaw, 2007). Bu süreçte başta düşük maliyetli havayolu işletmeleri tarafından olmak üzere internet siteleri bilet satmak, check-in vb. birçok online hizmet sunumunda kullanılmaya başlanmıştır (Sismanidou vd., 2009). Havayolu internet siteleri sayesinde yolcular düşük ücretlerle yer ve zaman kısıtı bulunmaksızın bilet satın alma olanağına kavuşurken, aynı zamanda uçuşlarına ilişkin tüm çevrimiçi işlemleri (online check-in, bagaj takibi, koltuk seçimi, ek hizmetler vb.) hızlı ve kolayca yerine getirebilmektedirler (Güreş vd., 2015).

Internet sitelerinin aktif kullanılmasıyla birlikte havayolu işletmelerinin kullandığı önemli rekabet araçlarından biri olan hizmet kalitesi sanal ortamda da e-hizmet kalitesi olarak karşımıza çıkmaya başlamış ve müşteri memnuniyeti ve müşteri bağlılığı gibi kavramlarla yakın ilişkisinden dolayı araştırılmaya değer bir kavram haline gelmiştir. Dolayısıyla bu çalışmada ehizmet kalitesini etkileyen kriterlerin önem düzeyleri havayolu işletmeleri ve havayolu sektörü özelinde değerlendirilmiştir. Hizmet kalitesi kavramına benzer şekilde e-hizmet kalitesi kavramının çok boyutlu bir yapıda olması nedeniyle Çok Kriterli Karar Verme (ÇKKV) yöntemlerinin çalışmadan yöntem olarak kullanımının uygun olacağı düşünülmüştür.

Çalışma 5 bölümden oluşmaktadır. Illk bölümü çalışmanın amacının açıklandığı giriş bölümü oluştururken, ikinci bölümde e-hizmet kalitesi kavramına yer verilerek literatürde yapılmış çalışmaların özetlendiği yazın taraması bölümü yer almıştır. Üçüncü bölümde çalışmada kullanılan araştırma yöntemine yer verilirken, dördüncü bölümde uygulama gerçekleştirilerek ehizmet kalitesini etkileyen kriterlerin ağılıkları elde edilmiştir. Çalışmanın son bölümü olan sonuç bölümünde ise edinilen bulgular yorumlanmış ve birtakım öneriler sıralanmıştır.

\section{Yazın Taraması}

Günlük yaşantımızda oldukça geniş bir yelpazede karşımıza çıkan hizmet kavramı " bir tarafın diğerine sunabileceği temel olarak somut olmayan ve herhangi bir sahiplikle sonuçlanmayan fiil ya da performans" olarak tanımlanmaktadır (Kotler ve Keller, 2012). Diğer yandan 21. Yüzyılda bilgi teknolojilerinde yaşanan gelişmeler neticesinde ticari faaliyetlerin yeniden yapılanması neticesinde hizmetlerin sanal ortam üzerinden sunumunu kapsayan e-ticaret ve e-hizmet gibi kavramlar hayatımıza dâhil olmuştur. 1990' ların ortalarından bu yana işletmeler tarafından kullanıldığı bilinen e-ticaret kavramı, internet teknolojilerinin geleneksel ticarete entegre edilmesinden ibaret olarak görülmektedir (Marangoz, 2014). E-hizmetler ise "bilgi teknolojileri vasıtasıyla yürütülen işler, eylemler ve performanslar" olarak tanımlanmaktadır (Rowley, 2006). Bir self-servis deneyimini ifade eden e-hizmet kavramı aynı zamanda "herhangi bir görevliye ihtiyaç duyulmaksızın müşterilerin hizmet işletmesini temsil eden bir internet sitesiyle etkileşimi neticesinde deneyimledikleri bir self-servis süreci" olarak tanımlanmaktadır (Çelik ve Başaran, 2008). 
Günümüzde e-hizmetler yoğun bir şekilde kullanılırken bahsedilen sürecin başarılı bir şekilde gerçekleşmesini ifade eden e-hizmet kalitesi kavramı ayrı bir öneme kavuşmuştur. Ehizmet kalitesi kavramı "tüketicilerin sanal ortamda sunulan hizmetler hakkında edindikleri kalitenin temel değerlendirmesi" olarak tanımlanmaktadır (Santos, 2003). Diğer yandan Çelik ve Başaran (2008) tarafından yapılan e-hizmet tanımı dikkate alındığında hizmet sunumu aracı olarak internet siteleri öne çıkmaktadır ki bu noktada e-hizmet kalitesi " web sitelerin kullanıcı ihtiyaç ve beklentilerini karşılamaya yönelik etkin hizmet sunma kabiliyeti" olarak da tanımlanabilmektedir (Majid vd., 2015). Literatürde temel olarak müşterilerin çevrimiçi hizmetlerden beklentilerini ifade eden e-hizmet kalitesi kavramı yapılan araştırmalarda çevrimiçi hizmet kalitesi, website hizmet kalitesi ve e-hizmet kalitesi vb. başıkları altında karşımıza çıkmaktadır (Al-Momani ve Noor, 2009).

İnternet pazarlaması ve e-hizmetler üzerinde yapılan çalışmaların artmasıyla birlikte ehizmet kalitesi kavramı işletmelerin başarısı veya başarısızlığı üzerinde oldukça etkili olması nedeniyle önemli bir araştırma konusu haline gelmiştir. 2000-2014 yıllarını kapsayan ve 31264 katılımcıyı kapsayan bir meta-analiz çalışması e-hizmet kalitesinin müşteri memnuniyeti, müşteri bağlılığı ve yeniden satın alma niyetinin önemli bir öncülü olduğu ve bu değişkenleri doğrudan etkilediğini göstermektedir (Blut vd., 2015). Diğer yandan, araştırmalar 2000 yılında 19 milyar \$, 2001 yılında ise 16 milyar \$ değerinde satış fırsatının kötü e-hizmet kalitesi nedeniyle kaçırıldığını göstermektedir. Bu rakamlar e-hizmet kalitesinin işletmeler açısından önemini göstermesi bakımından oldukça önemlidir (Çelik ve Başaran, 2008).

E-hizmet ve e-hizmet kalitesi kavramları tüm işletmelerde olduğu gibi havayolu taşımacılığı sektörü ve havayolu işletmeleri açısından da kritik öneme sahiptir. Tüketiciler teknoloji kullanımının yaygınlaşması ile birlikte yer ve zaman sorunu yaşamadan daha düşük maliyetlere katlanarak havayolu hizmetlerini internet siteleri vasıtasıyla edinmeye başlamışlardır. Nitekim günümüzde havayolu işletmeleri de internet siteleri üzerinden hizmetlerini sunmaya yoğun bir şekilde devam etmektedirler (Tsai vd., 2011).

E-hizmetler, işletmeler ve tüketiciler tarafından yoğun bir şekilde kullanılmakla birlikte aynı zamanda bu alandaki araştırmalar da sürmektedir. Bu çalışmaların başında e-hizmet kalitesini oluşturan boyutların tespiti ve e-hizmet kalitesinin müşteri memnuniyeti gibi birtakım değişkenlerle ilişkisi gibi konular gelmektedir. Hizmet kalitesinde geçerli olduğu gibi e-hizmet kalitesinin çok boyutlu bir yapıya sahip olduğu ve dolayısıyla ölçümün zor olduğu düşünülmektedir (Chou ve Cheng, 2012). Literatürdeki çalışmalar ele alındığında e-hizmet kalitesi ölçümünde birçok farklı yapının ve modelin önerildiği bilinmektedir. Bununla birlikte, e-hizmet kalitesinin e-hizmetlerin yoğun bir şekilde kullanıldığı havayolu taşımacılı̆̆ı sektörüne odaklanılarak ele alındığı çalışmalarda mevcuttur.

Bu doğrultuda, Shchiglik ve Barnes (2004), Yeni Zelanda' da faaliyet gösteren havayolu işletmelerinde sunulan e-hizmetlere yönelik tüketici algılarını incelemişlerdir. 3 havayolunun ele alındığı bu çalışmada, doğrudan kalite boyutlarına odaklanıımış ve site kalitesi, bilgi kalitesi, tasarım kalitesi ve havayoluna özgü kalite gibi kalite boyutları kullanılmıştır. Xie ve Barnes (2008) ise İngiltere' de faaliyet gösteren 4 havayolunun 1999-2005 periyodunda gösterdikleri e-hizmet kalitesi performansını değerlendirmişlerdir. Bu çalışmada da e-hizmet kalitesi beş boyut altında incelenmiş olup, bunlar kullanışlılık, bilgi kalitesi, hizmet kalitesi, eğlendiricilik ve site tasarımıdır. Bakır ve Atalık (2017), Türkiye' de yolcular üzerinde yaptıkları çalışmada ehizmet kalitesini bilgi kalitesi, etkileşim kalitesi, tasarım kalitesi ve firmaya özgü kalite olarak 
ele almışlar ve Y Kuşağı'na odaklandıkları bu çalışmada e-hizmet kalitesine yönelik algıları demografik değişkenlere göre incelemişlerdir.

Diğer yandan e-hizmet kalitesinin memnuniyet ve yeniden satın alma niyeti gibi değişkenlerle ilişkisinin ele alındığı çalışmalar da mevcuttur. Örneğin, Sam ve Tahir (2009), Malezya' da havayolu işletmelerinde e-hizmet kalitesi boyutları ile satın alma eğilimi arasındaki ilişkiyi incelemişlerdir. Diğer yandan Lau ve diğerleri (2011), Malezya' da e-hizmet kalitesi ile satın alma niyeti ve müşteri memnuniyeti arasındaki ilişkiyi; Lee ve Wu (2011), Tayvan' da e-hizmet kalitesi ile müşteri memnuniyeti ve algılanan değer arasındaki ilişkiyi; Majid ve diğerleri (2015) e-hizmet kalitesi boyutlarının müşteri memnuniyeti üzerindeki etkisini ve Güreş ve diğerleri (2015), Türkiye' de e-hizmet kalitesinin yolcu memnuniyeti üzerindeki etkisini ve yolcu memnuniyetinin de yolcu bağlılığı üzerindeki etkisini incelemişlerdir.

Diğer yandan literatür incelendiğinde, birçok farklı alanda olduğu gibi havayollarında ehizmet kalitesine yönelik çalışmalarda da metodolojik olarak ÇKKV yöntemlerinin tercih edilmeye başlandığı bilinmektedir. Bu kapsamda, Tsai ve diğerleri (2011), DEMATEL, ANP ve VIKOR yöntemlerini kullandıkları çalışmada havayolu işletmeleri üzerinde ÇKKV yöntemleri ile pazarlama karması ve website kalitesi başlıklarını incelemişlerdir. Bu çalışmada en önemli website kalitesi kriterinin güvenilirlik olduğu belirlenmiştir. Diğer yandan Çelik ve Gök Kısa (2017) da Bulanık AHP ve Bulanık Promethee yöntemleri yardımıyla havayolu işletmelerinin sunduğu e-hizmetlerde kaliteyi etkileyen kriterlerin önem düzeylerini incelemişlerdir. Parasuraman ve diğerleri (2005) tarafından öne sürülen kalite boyutlarının kullanıldığı bu çalışmada gizlilik ve güvenlik unsurlarının öne çıktığı tespit edilmiştir. Son olarak havayolu işletmelerinin web siteleri üzerine odaklanan ve ÇKKV yöntemlerinin kullanıldığı çalışmalarda mevcuttur. Fakat bu çalışmalarda e-hizmetlerde beklentiyi konu alan kalite kriterlerinden ziyade altyapısal performansı ölçen ve "Web Tanı Aracı" kapsamında kullanılan bazı kriterler kullanıımıştır (Jati, 2009; Dominic ve Khan, 2014; Vatansever ve Akgül, 2018).

\section{Araştırma Yöntemi}

\subsection{Araştırmanın Amacı ve Önemi}

1990’ Iı yıllarda internetin sivil amaçla kullanıma açılması ile birlikte dünyada büyük bir dönüşüm süreci yaşanmış ve havayolu taşımacılığı sektörü bu gelişmeden en fazla etkilenen sektörlerden biri olmuştur. Bu dönemde başta düşük maliyetli taşıyıcılar olmak üzere havayolu işletmeleri daha etkin hizmet sunabilmek, dağıtım maliyetlerini düşürerek rekabet üstünlüğü elde edebilmek amacıyla interneti dolayısıyla web siteleri büyük bir fırsat olarak görmeye başlamışlardır. Günümüzde ise havayolu işletmelerinin hizmetlerinin dağıtımında kullandığı satış ofisleri, çağrı satış makinaları ve kiosklar sıklıkla kullanılsa da en büyük gelişme havayolu internet sitelerinde yaşanmıştır (Shaw, 2007). Nitekim SITA (2016) tarafından 19 ülke çapında yapılan bir araştırma sonuçları havayolu hizmetlerinde teknoloji kullanımının yükselen trendini gözler önüne sermektedir. Buna göre bilet satın alan yolcuların $\% 75^{\prime}$ i ve check-in yapan yolcuların \%31' i havayolu internet sitelerini kullanmaktadır. Internet kullanımının geçmişten günümüze gösterdiği gelişim süreci Şekil 1' de görülmektedir. 
Kaynak: (Wensveen, 2007: 268; SITA, 2016).

Bu çalışmada havayollarında e-hizmetlerin yoğun bir şekilde kullanımından dolayı e-hizmet kalitesi üzerinde etkisi olan kriterlerin belirlenmesi ve önem düzeylerinin elde edilmesi amaçlanmıştır. Havayolu işletmelerinde e-hizmet kalitesinin ÇKKV yöntemlerinden AHP yöntemi ile ele alındığı bu çalışmanın önemi teorik ve pratik açılardan ele alınabilir. Öncelikle literatür ele alındığında, e-hizmet kalitesini ÇKKV yöntemleri ile ele alan çalışmaların az sayıda olduğu (Lee ve Kozar, 2006; Lin, 2010; Ustasüleyman, 2013), havacılık alanında ise nadiren çalışıldığı görülmektedir (Tsai vd., 2011; Çelik ve Gök Kısa, 2017). Dolayısıyla literatürdeki boşluğun doldurulması adına çalışmanın faydalı olabileceği düşünülmektedir. Diğer yandan, havayolu işletmelerinin sunduğu e-hizmetleri etkileyen unsurların önem düzeylerinin belirlenmesinin işletmelere bu yönde adım atma fırsatı sunacağı düşünülmektedir.

\subsection{Araştırmanın Yöntemi}

Bu çalışmada, havayolu taşımacılığı sektöründe e-hizmet kalite boyutlarının önem düzeylerinin belirlenmesinde AHP yöntemi kullanılmıştır.

\subsubsection{AHP (Analitik Hiyerarşi Prosesi) Yöntemi}

AHP yöntemi, karar verme problemlerinde kullanılan, içerisinde barındığı hiyerarşinin her seviyesinde yer alan ögelerin bir matris yardımıyla ikili karşılaştırılmasını ve bu sayede ögelerin önem derecelerinin belirlenmesini sağlayan bir yöntemdir (Wind ve Saaty, 1980: 641).

AHP yönteminde hiyerarşik yapı oluşturulurken, hiyerarşideki seviye sayısı problemin detay derecesine ve karmaşıklığına bağlı olarak farklılık göstermektedir (Ömürbek ve Şimşek, 2012: 118). AHP' nin en önemli avantajlarından biri oran ölçekleri ile maddi olmayan ölçütlerin de ölçülmesine olanak tanımasıdır. Yöntemin bir diğer avantajı ise hiyerarşik yapının kurulması ile problemin oldukça detaylı bir şekilde gözler önüne serilebilmesidir (Sarıçalı ve Kundakçı, 2016: 47).

ÇKKV problemlerinin çözümünde kullanılan birçok yöntem olmasına karşın AHP yöntemi teknik olarak ciddi bir yetkinlik gerektirmemesi, nitel kriterlerin de değerlendirilmesine olanak tanıması ve hem birey hem de grup kararlarına uygun olması gibi nedenlerden dolayı yaygın bir şekilde kullanılmaktadır (Ömürbek ve Şimşek, 2012: 118):

AHP yöntemi uygulaması aşağıdaki şekildedir (Supçiller ve Çapraz, 2011: 6-9; Sarıçalı ve Kundakçı, 2016: 47-50):

Adım 1: Karar probleminin tanımlanması ve hiyerarşik yapının kurulması

AHP yöntemi uygulamasında ilk adımda problemi oluşturan unsurların bilinmesi ve hiyerarşik yapının kurulması gerekir. Problemi oluşturan unsurların belirlenmesinde literatürden 
veya uzman görüşlerinden yararlanılır (Kecek ve Yıldırım, 2010: 198). Probleme ilişkin yeterli bilginin edinilmesi ardından ise bu bilgilerden yola çıkarak amaç, kriterler ve alternatifler belirlenerek hiyerarşik yapı kurulur. Örnek bir hiyerarşik yapı modeli Şekil 2' de görülmektedir.

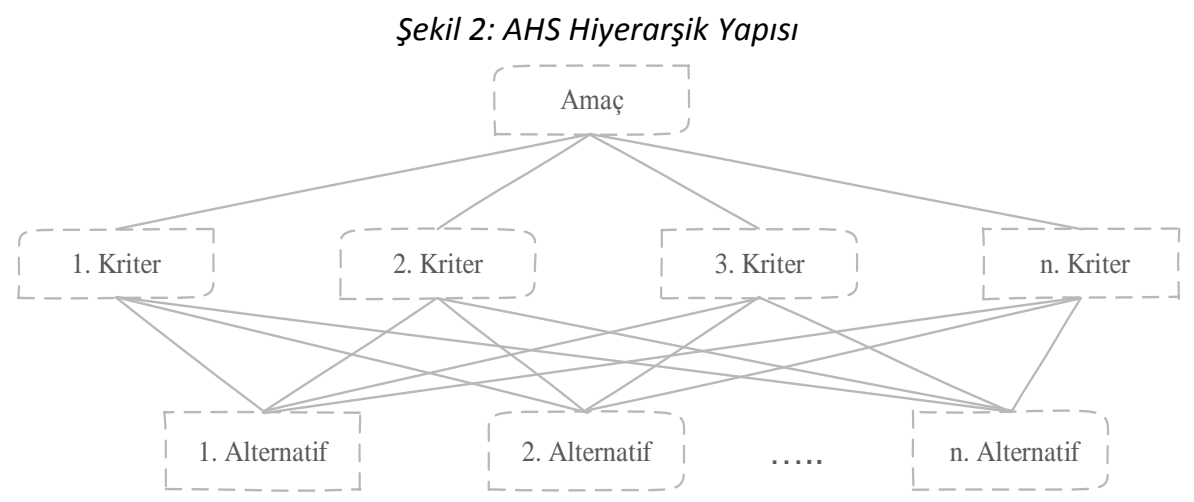

Kaynak: (Sarıçalı ve Kundakçı, 2016: 48)

Adım 2: ikili karşılaştırma matrislerinin oluşturulması

Bu aşamada hiyerarşik yapıda yer alan kriterler, alt kriterler ve alternatifler ikili olarak karşılaştırılır. Burada elde edilen değerler, kriter veya alternatiflerin karşılaştırıldıkları diğer ögeye göre görece önemlerini ifade etmekle birlikte işlem sonucunda eşitlik (1)' de yer alan matris elde edilmektedir.

$$
A=\left[\begin{array}{cccc}
a_{11} & a_{12} & \cdots & a_{1 n} \\
a_{21} & a_{22} & \cdots & a_{2 n} \\
\cdot & & & \cdot \\
a_{n 1} & a_{n 2} & \cdots & a_{n n}
\end{array}\right]
$$

Eşitlik (1)' de görülen matris üzerinde ikili karşılaştırmaların problem hakkında uzman kişiler tarafından ele alınması gerekirken karşılaştırmalarda Saaty tarafından geliştirilen ve Tablo 1' de görülen önem ölçeği kullanılmaktadır (Tütek vd., 2012; Saaty, 1990).

Tablo 1: Ikili Karşılaştırma Önem Ölçeği

\begin{tabular}{clc}
\hline Ö. Derec. & \multicolumn{1}{c}{ Tanım } & Açıklama \\
\hline $\mathbf{1}$ & Eşit düzeyde önemli & iki kriterin amaca katkısı eşit düzeyde \\
$\mathbf{3}$ & Kısmi düzeyde önemli & $\begin{array}{c}\text { Tecrübe ve yargılara göre bir kriterin diğerine nispeten kısmi } \\
\text { düzeyde önemli olması } \\
\mathbf{5}\end{array}$ \\
& Kuvvetli düzeyde önemli & $\begin{array}{c}\text { Tecrübe ve yargılara göre bir kriterin diğerinden kuvvetli düzey- } \\
\text { de önemli olması }\end{array}$ \\
$\mathbf{7}$ & Çok kuvvetli düzeyde önemli & Bir kriterin diğerinden çok kuvvetli düzeyde önemli olması \\
$\mathbf{9}$ & Aşırı düzeyde önemli & Bir kriterin diğerinden aşırı düzeyde önemli olması \\
$\mathbf{2 , 4 , 6 , 8}$ & Ara Değerler & Uzlaşma durumlarında iki ardışık yargı arasına düşen değerler \\
\hline
\end{tabular}

Kaynak: (Saaty, 1990)

AHP yöntemiyle ele alınan problemlerde daha çok uzman görüşleri kullanıldığı için yöntemin daha çok grup kararlarında kullanıldığı söylenebilir. Bu durumda analize devam edebilmek için karar vericilerden alınan karşılaştırma matrislerinin birleştirilmesi (aggregation) yoluyla yeni ve tek bir karşılaştırma matrisinin oluşturulması gerekmektedir. Literatürde bu birleştir- 
me işleminin gerçekleştirilmesinde ise farklı matrislerin geometrik ortalama yoluyla birleştirilmesi önerilmektedir ${ }^{4}$ (Kuruüzüm ve Atsan, 2001).

\section{Adım 3: Kriterlerin önem düzeylerinin belirlenmesi}

Bu aşamada kriterlerinin önem düzeyleri (özvektörleri) hesaplanır. Bu adımda elde edilen kriter önem düzeyleri, ilgili kriterin tüm kriterler içerisindeki öneminin bir ifadesidir. Karşılaştırma matrisine ait önem düzeylerinin hesaplanmasında eşitlik (2) kullanılmaktadır.

$$
b_{i j}=\frac{a_{i j}}{\sum_{i=1}^{n} a_{i j}} \quad w_{i}=\frac{\sum_{j=1}^{n} b_{i j}}{n}
$$

Eşitlik (2)' de görülen işlem sonucunda özvektör olarak adlandırılan ve eşitlik (3)' de gösterilen $w_{i}$ önem dereceleri elde edilmektedir.

$$
w_{i}=\left[\begin{array}{c}
w_{1} \\
w_{2} \\
\cdot \\
w_{n}
\end{array}\right]
$$

\section{Adım 4: Tutarlılık oranının hesaplanması}

AHP yönteminde yapılan değerlendirmeler karar vericilerin görüşlerini yansıttığı için sübjektiftir ve bu noktada birtakım tutarsızlıkların ortaya çıkması kaçınılmaz hale gelebilmektedir (Tütek vd., 2012). AHP yönteminde bu tutarsızlıkların elimine edilmesi amacıyla tutarlılık oranı $(C R)$ olarak adlandırılan değer kullanılmaktadır. $C R$ değeri için ilk olarak başlangıç matrisinin en büyük özvektörü $\left(\lambda_{\max }\right)$ hesaplanmalıdır. Bu işlem eşitlik (4-5) yardımıyla gerçekleştirilmektedir.

$$
\begin{gathered}
D=\left[\begin{array}{cccc}
a_{11} & a_{12} & \cdots & a_{1 n} \\
a_{21} & a_{22} & \ldots & a_{2 n} \\
\cdot & \cdot & \cdot & \cdot \\
a_{n 1} & a_{n 2} & \cdots & a_{n n}
\end{array}\right] x\left[\begin{array}{c}
w_{1} \\
w_{2} \\
\cdot \\
w_{n}
\end{array}\right]=\left[\begin{array}{c}
d_{1} \\
d_{2} \\
\cdot \\
d_{n}
\end{array}\right] \\
\lambda_{\max }=\frac{\sum_{i=1}^{n} \frac{d_{i}}{w_{i}}}{n}
\end{gathered}
$$

Eşitlik (5)' de hesaplanan " $\lambda_{\max }$ "değeri " $n$ " değerine eşit veya büyük olmalıdır. Diğer bir deyişle, tutarlılık indeksi $(C I)$ değerinin bulunmasında kullanılan " $\lambda_{\max }-n$ " değeri tutarsızlık derecesi için önemli bir ölçüt olarak görülmektedir (Tütek vd., 2012: 349). Bahsedilen tutarlılık indeksi (CI) değeri eşitlik (6) yardımıyla hesaplanmaktadır.

$$
C I=\frac{\lambda_{\max }-n}{n-1}
$$

Tutarlılık oranının hesaplanmasında kullanılan son değer ise rassalık indeksi $(R I)$ değeridir. Rassalık indeksi değeri matriste yer alan öge sayısına göre belirlenirken bu amaçla Tablo 2' de görülen değerler dikkate alınmaktadır.

Tablo 2: Rassal indeks Değerleri

\begin{tabular}{ccccccccccc}
\hline $\boldsymbol{n}$ & $\mathbf{1}$ & $\mathbf{2}$ & $\mathbf{3}$ & $\mathbf{4}$ & $\mathbf{5}$ & $\mathbf{6}$ & $\mathbf{7}$ & $\mathbf{8}$ & $\mathbf{9}$ & $\mathbf{1 0}$ \\
\hline $\boldsymbol{R I}$ & 0 & 0 & 0,58 & 0,9 & 1,12 & 1,24 & 1,32 & 1,41 & 1,45 & 1,45 \\
\hline
\end{tabular}

\footnotetext{
${ }^{4}$ Bazı çalışmalarda aritmetik ortalama da kullanılmasına karşın literatürde genellikle geometrik ortalamanın kullanıması önerilmektedir (Saaty, 2008: 95; Kuruüzüm ve Atsan, 2001: 92).
} 
Tutarlılık oranı hesaplamasının son aşamasında eşitlik (7)' de görülen işlem gerçekleştirilir

$$
C R=\frac{C I}{R I}
$$

Yapılan hesaplama sonucunda $C R$ değerinin 0,10'dan küçük olması durumunda karar matrisinin tutarlı olduğu kabul edilmektedir (Kwiesielewicz ve Van Uden, 2004: 714). Aksi durumda karşılaştırma matrisinin tutarlığının sağlanması için değişiklikler yapmak gerekmektedir (Saaty, 1990: 13).

\section{Adım 5: Nihai özvektörlerinin elde edilmesi}

AHP yönteminin temel prensiplerinden sentez işleminin gerçekleştirildiği bu aşamada, ikili karşılaştırmalardan elde edilen ögelere ait önem dereceleri, bağı oldukları bir üst seviyedeki ögenin önem derecesi ile çarpılarak R sonuç vektörüne ulaşılır. İkili karşılaştırmalar sonucu elde edilen önem dereceleri, ögelerin lokal özvektörlerini oluştururken, sentez işlemi sonucunda ise ögelerin global (nihai) özvektörleri elde edilmektedir.

\subsection{Anket Tasarımı}

Verilerin toplanması sürecinde, araştırmaya katılan katılımcılara e-hizmet kalitesini etkileyen kriterleri ikili olarak karşılaştırabilmelerini sağlayacak anket formları dağıtılmıştır. Anket formu içeriğinde öncelikle çalışmada yer alan kriter ve alt kriterler belirtilirken, ardından çaış̧madaki her bir unsura ilişkin açıklamaya yer verilmiştir ve uygulamanın nasıl gerçekleştirileceğine dair örnek gösterilmiştir. Daha sonra ise katılımcılardan kriter ve alt kriterleri kendi aralarında karşılaştırmaları istenmiştir. Anket formunun bir bölümü Şekil 3’ de görülmektedir.

\section{Şekil 3: Anket formunda yer alan anket soruları}

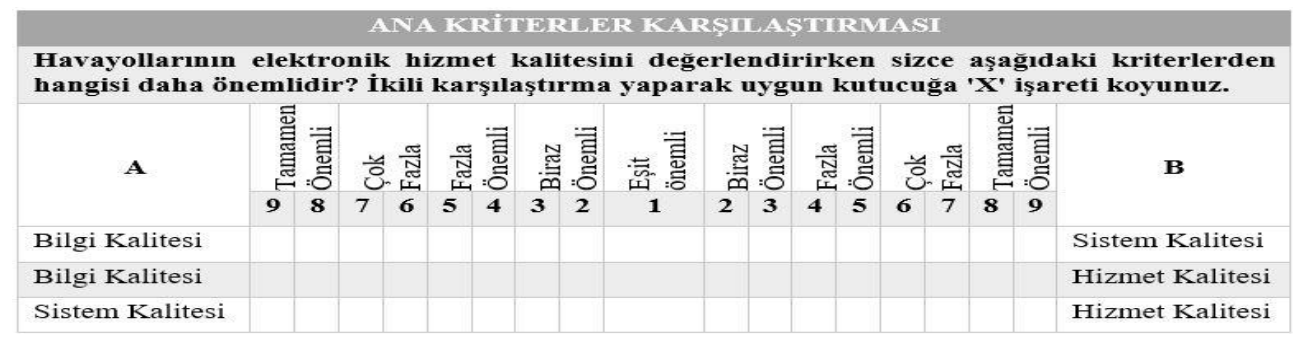

\section{4. Örneklem}

Kriter ağırlıklarının belirlenmesinin amaçlandığı bu çalışmada, yöntemin uygulanma zorluğu nedeniyle web tabanlı e-hizmetlerde kaliteyi etkileyen kriterlerin önem düzeylerini toplamda 11 karar vericinin değerlendirmesi istenmiştir.Veriler araştırmacılardan Haziran 2017Temmuz 2017 arasını kapsayan dönemde elde edilmiş ve değerlendirmeye alınmıştır.

AHP yöntemi ile grup kararları alınırken uzmanlara veya konuya aşina kişilere başvurulması önerildiği için (Kuruüzüm ve Atsan, 2001: 87), uzman seçiminde e-hizmet konusuna hâkim olma ve havayolu taşımacılığını sıklıkla kullanma gibi kriterler dikkate alınmıştır. Dolayısıyla çalışma kapsamında görüşlerine başvurulan karar vericiler grubu internet sitesi tasarımcısı, havayolu çalışanı ve havacılık alanında akademik çalışmalar yürüten kişilerden oluşturulmuştur. AHS yöntemi, uzmanlara ait kararların geometrik ortalama yöntemiyle birleştirilmesine olanak tanıdığı için uzmanların farklı alanlardan seçilmesinin konuya farklı bakış açıları getirilmesi yönünde katkı sağlayacağı düşünülmüştür. Literatürde AHP yönteminde örneklem büyüklüğüne ilişkin belirli bir sayı verilmediğinden ötürü uzman sayısının yeterli olduğu düşünülmektedir. 


\section{Uygulama}

$\mathrm{Bu}$ bölümde, havayolu işletmelerinde sunulan e-hizmet kalitesini etkileyen unsurların önem düzeyleri AHP yöntemi yardımıyla elde edilmiştir. Bugüne kadar e-hizmetlerde kalite ölçümünde birçok model ve değerlendirme kriterinin önerildiği görülmektedir. Buna karşın ehizmet kalitesi ölçümünde metodolojik farklılıklar olduğu ve bu amaçla kullanılan yöntemlerden birinin ÇKKV yöntemleri olduğu görülmektedir. ÇKKV yöntemiyle ele alınmış çalışmalar ele alındığında görüş birliğine varılmış bir yapıya ulaşılamamıştır. Web tabanlı e-hizmetlere odaklanılan bu çalışmada değerlendirme kriterlerinin seçiminde literatürde de sıklıkla kullanılan üç boyutlu hiyerarşik yapıdan faydalanılmıştır (Nilashi vd., 2012; Chou ve Cheng, 2012; Ecer, 2014). Bu kapsamda oluşturulan hiyerarşik model Şekil 4' de görülmektedir.

Şekil 4: E-hizmet Kalitesi Performansı Modeli

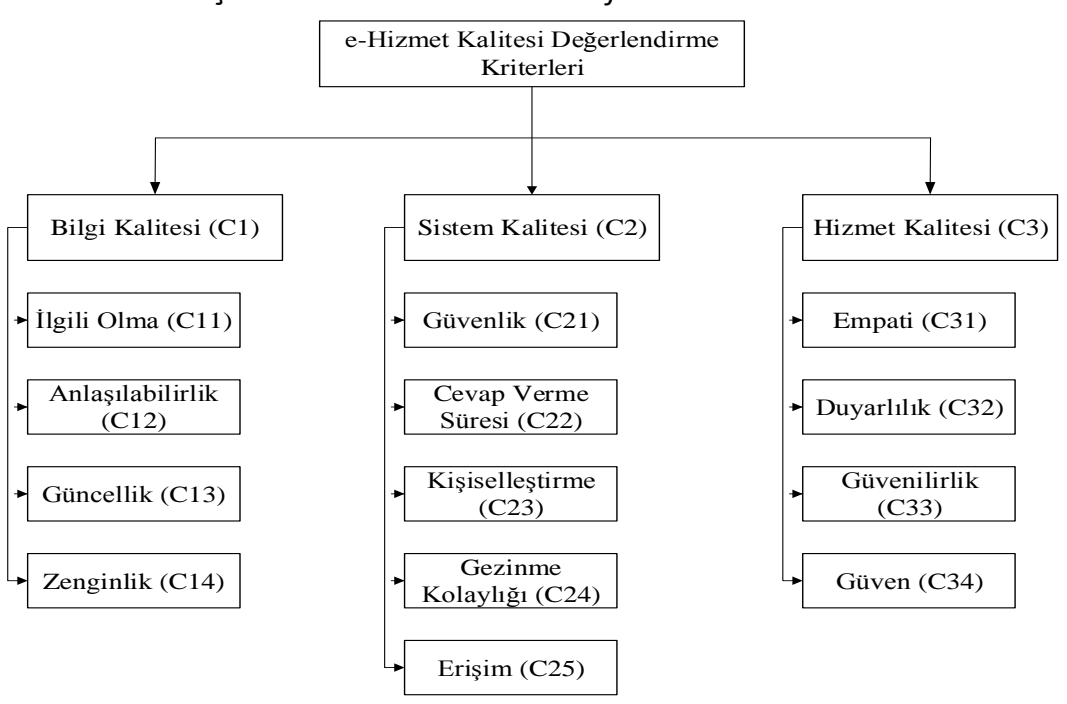

Şekil 4' de görülen modelin ilk aşamasında problemin amacı yer alırken, ikinci aşamada değerlendirme kriterleri ve üçüncü aşamada değerlendirme kriterlerine bağlı alt kriterler yer almaktadır. Buna göre e-hizmet kalitesinin bilgi kalitesi, sistem kalitesi ve hizmet kalitesi olmak üzere 3 temel boyutu bulunmaktadır. Bu boyutlara bağlı olan alt kriterler dikkate alındığında ise e-hizmet kalitesinde 13 alt kriterin etkili olduğu görülmektedir. Çalışmada kullanılan kriterlere ilişkin açıklamalar ve kriterlerin alındığı çalışmalar Tablo 3 ve Tablo 4' de görülmektedir. 


\section{Eskişehir Osmangazi Üniversitesi IïBF Dergisi}

Tablo 3: E-hizmet Kalitesi Kriterleri ve Açıklamaları

\begin{tabular}{ll}
\hline \multicolumn{1}{c}{ Kriterler } & Açıklama \\
\hline Bilgi Kalitesi & Web sitenin sunduğu veya ürettiği bilginin uygunluğunu ifade eder. \\
\hline illgili olma & Web sitedeki bilginin müşteri ihtiyaç ve beklentilerine uygunluğunu ifade eder. \\
Anlaşılabilirlik & Web sitedeki bilgilerin açıklığı ve netliğini, kolay anlaşılabilmesini ifade eder. \\
Güncellik & Web sitede yer alan bilgilerin güncelliğini ifade eder. \\
Zenginlik & Web sitenin sunduğu hizmet hakkında geniş kapsamlı bilginin varlığını ifade eder. \\
\hline Sistem Kalitesi & Web sitenin teknolojik donanımı ve altyapı kalitesini ifade eder. \\
\hline Güvenlik & Müşteri bilgilerinin gizli tutulması ve korunmasını ifade eder. \\
Cevap verme & Müşterinin bulmak istediği sonuçların çabuk yüklenmesi ve isteklerine hızlı cevap verilmesini ifade \\
süresi & eder. \\
Kişiselleştirme & $\begin{array}{l}\text { Web sitenin ve hizmetlerin her bir müşteriye özel hale getirilmesi ve ihtiyaçları doğrultusunda } \\
\text { farklılaştırılmasını ifade eder. }\end{array}$ \\
Gezinme & Web sitenin kolay kullanılabilmesini ve istenilen bilgiye kolayca erişmeyi ifade eder. \\
kolaylığı & Web siteye erişim kolaylığını ifade eder. \\
Erişim & Verilen hizmetin başarılı bir şekilde yerine getirilmesini veya gerçekleştirilmesini ifade eder. \\
\hline Hizmet kalitesi & Müşteriyi anlama ve onun isteklerine yönelik faaliyet gösterme durumunu ifade eder. \\
\hline Empati & Çevrimiçi müşterilere hızlı hizmet sunma ve yardım etme istekliliğini ifade eder. \\
Duyarlılık & Web sitenin sunduğu hizmetin doğruluğu ve hizmetin söz verilen şekilde yerine getirilmesini ifade \\
Güvenilirlik & $\begin{array}{l}\text { eder. } \\
\text { Hizmetlerin iyi bir üne sahip olması ve siteyi kullanmanın güven verici, rahatlatıcı olmasını ifade } \\
\text { eder. }\end{array}$ \\
\hline
\end{tabular}

Tablo 4: Değerlendirme Kriterleri ve Kaynakları

\begin{tabular}{|c|c|c|}
\hline Kriter & Alt Kriter & Kaynaklar \\
\hline \multirow{4}{*}{ Bilgi Kalitesi } & İlgili olma & (Lee ve Kozar, 2006; Tsai ve diğerleri, 2010; Ustasüleyman, 2013) \\
\hline & Anlaşılabilirlik & (Loiacono ve diğerleri, 2002; Lee ve Kozar, 2006; Chou ve Cheng, 2012) \\
\hline & Güncellik & (Jun ve Cai, 2001; Tsai ve diğerleri, 2010; Ecer, 2014) \\
\hline & Zenginlik & (Tsai ve diğerleri, 2010; Ustasüleyman, 2013; Ecer, 2014) \\
\hline \multirow{5}{*}{ Sistem Kalitesi } & Güvenlik & (Jun ve Cai, 2001; Loiacono ve diğerleri, 2002; Wolfinbarger ve Gilly, 2003) \\
\hline & $\begin{array}{l}\text { Cevap verme } \\
\text { süresi }\end{array}$ & (Lee ve Kozar, 2006; Lin, 2010; Nilashi ve diğerleri, 2012) \\
\hline & Kişiselleştirme & (Lee ve Kozar, 2006; Rowley, 2006; Vatansever ve Akgül, 2014) \\
\hline & $\begin{array}{l}\text { Gezinme kolay- } \\
\text { lığı }\end{array}$ & (Barnes ve Vidgen, 2001; Yoo ve Donthu, 2001; Tsai ve diğerleri, 2010) \\
\hline & Erişim & (Barnes ve Vidgen, 2001; Rowley, 2006; Chou ve Cheng, 2012) \\
\hline \multirow{4}{*}{$\begin{array}{l}\text { Hizmet Kalite- } \\
\text { si }\end{array}$} & Empati & (Jun ve Cai, 2001; Madu ve Madu, 2002; Ecer, 2014; Nilashi ve diğerleri, 2012) \\
\hline & Duyarlılık & (Kaynama ve Black, 2000; Long ve McMellon, 2004; Chou ve Cheng, 2012) \\
\hline & Güvenilirlik & (Jun ve Cai, 2001; Madu ve Madu, 2002; Wolfinbarger ve Gilly, 2003; Lin, 2010) \\
\hline & Güven & (Madu ve Madu, 2002; Chou ve Cheng, 2012; Ecer, 2014; Nilashi ve diğerleri, 2012) \\
\hline
\end{tabular}

Uygulama bölümünde analizler gerçekleştirilirken "Microsoft Office Excel 2016" ve "SuperDecisions" paket programları kullanılmıştır ve çalışmada önerilen metodoloji şekil 5' de gösterilmiştir. 
Şekil 5: Çalışma Kapsamında Önerilen Metodoloji
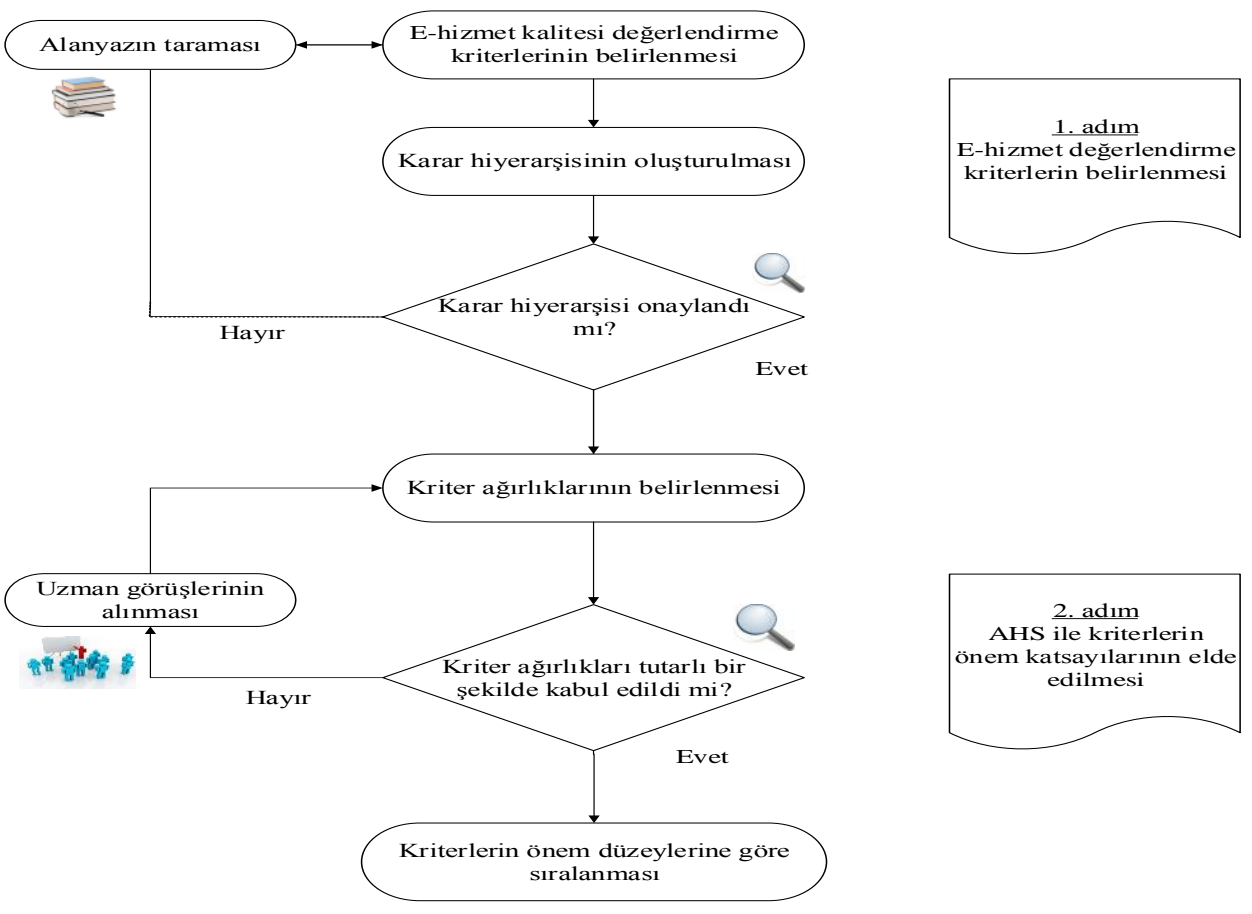

\subsection{Ana Kriterlere İlişkin Önem Derecelerinin Belirlenmesi}

Uygulama kısmında öncelikle 3 ana kriter ikili olarak karşılaştırılmış ve oluşan karar matrisi Tablo 5' de verilmiştir.

Tablo 5: Ana Kriterler İ̧̧in Ikili Karşılaştırma Matrisi

\begin{tabular}{lccc}
\hline & C1 & C2 & C3 \\
\hline C1 & 1,00 & 1,28 & 0,91 \\
C2 & 0,78 & 1,00 & 0,72 \\
C3 & 1,10 & 1,39 & 1,00 \\
\hline Toplam & 2,88 & 3,67 & 2,63 \\
\hline
\end{tabular}

Tablo 5' de görüldüğü gibi öncelikle kriterlerin, karşılaştırıldıkları diğer kriterlerden ne kadar daha önemli oldukları değerlendirilmiş ve matrise ait sütun toplamları hesaplanmıştır. Bu adımın ardından her bir sütun değerinin, sütun toplamlarına bölünmesiyle normalizasyon işlemi gerçekleştirilmiştir. Daha sonra satır toplamının ortalaması hesaplanmış ve böylece ağılıklar elde edilmiştir. Kriterlere ait ağırlıklar ve tutarlılığa ilişkin göstergeler Tablo 6’ da yer almaktadır.

Tablo 6: Ana Kriterler İçin Normalize Edilmiş Matris ve Özvektörler

\begin{tabular}{ccccc}
\hline & C1 & C2 & C3 & Özvektör \\
\hline C1 & 0,347 & 0,349 & 0,346 & 0,347 \\
C2 & 0,271 & 0,273 & 0,274 & 0,273 \\
C3 & 0,382 & 0,379 & 0,380 & 0,380 \\
& & & CR $=0,00002<0,10$ \\
\hline
\end{tabular}


Tablo 6’ da yer alan matrise göre en önemli kriter, 0,380 ağırık katsayısı ile hizmet kalitesi olarak belirlenmiştir. Kriterler önem derecelerine göre büyükten küçüğe doğru sıralandığında ikinci sırada bilgi kalitesi yer alırken, üçüncü sırada ise sistem kalitesinin yer aldığı görülmüştür. Karşılaştırma matrisi 0,00002 tutarlılık oranı ile tutarlı bulunmuştur.

\subsection{Alt Kriterlere iliş̧kin Önem Derecelerinin Belirlenmesi}

Bu bölümde sırasıyla ana kriterlere bağlı alt kriterler ikili olarak karşılaştırılmış ve alt kriterlerin önem dereceleri hesaplanmıştır.

Bilgi kalitesi alt kriterlerinin önem derecelerinin belirlenmesi:

Bu adımda bilgi kalitesi ana kriterinin alt kriterleri olan ilgili olma, anlaşılabilirlik, güncellik ve zenginlik alt kriterleri ikili olarak karşılaştırılmış ve oluşan karar matrisi Tablo 7' da verilmiştir.

Tablo 7: Bilgi Kalitesi Alt Kriterleri İ̧̧in Ikili Karşılaştırma Matrisi

\begin{tabular}{lllll}
\hline & C11 & C12 & C13 & C14 \\
\hline C11 & 1,00 & 0,72 & 0,76 & 1,75 \\
C12 & 1,39 & 1,00 & 1,38 & 2,66 \\
C13 & 1,32 & 0,72 & 1,00 & 2,33 \\
C14 & 0,57 & 0,38 & 0,43 & 1,00 \\
\hline Toplam & 4,28 & 2,82 & 3,57 & 7,74 \\
\hline
\end{tabular}

Tablo 7' de görüldüğü gibi bilgi kalitesine ilişkin matris üzerinde normalizasyon işlemi gerçekleştirilmiştir. Normalizasyon işlemi ile birlikte elde edilen özvektörler ve ikili karşılaştırma matrisine ilişkin tutarlılık göstergeleri Tablo 8' de verilmiştir.

Tablo 8: Bilgi Kalitesi İçin Normalize Edilmiş Matris ve Özvektörler

\begin{tabular}{cccccc}
\hline & C11 & C12 & C13 & C14 & Özvektör \\
\hline C11 & 0,234 & 0,255 & 0,213 & 0,226 & 0,232 \\
C12 & 0,325 & 0,355 & 0,387 & 0,344 & 0,352 \\
C13 & 0,308 & 0,257 & 0,280 & 0,301 & 0,286 \\
C14 & 0,134 & 0,133 & 0,120 & 0,129 & 0,129 \\
& & $\lambda_{\max }=4,00726$ & CR $=0,00269<0,10$ \\
\hline
\end{tabular}

Tablo 8' e göre yapılan ikili karşılaştırmalar sonucu en önemli alt kriterin 0,352 ağırlık katsayısı ile anlaşılabilirlik olduğu ortaya çıkmıştır. Anlaşılabilirlik alt kriterini ise sırasıyla güncellik, ilgili olma ve zenginlik alt kriterleri izlemektedir. Karşılaştırma matrisi 0,00269 tutarlılık oranı ile tutarlı bulunmuştur.

Sistem kalitesi alt kriterlerinin önem derecelerinin belirlenmesi:

Sistem kalitesi ana kriterine bağı olan güvenlik, cevap verme süresi, kişiselleştirme, gezinme kolaylığı ve erişim alt kriterleri ikili olarak karşılaştırılmış ve oluşturulan karar matrisi Tablo $9^{\prime}$ da verilmiştir. 
Tablo 9: Sistem Kalitesi Alt Kriterleri İçin Ikili Karşılaştırma Matrisi

\begin{tabular}{llllll}
\hline & C21 & C22 & C23 & C24 & C25 \\
\hline C21 & 1,00 & 4,39 & 5,11 & 3,56 & 1,63 \\
C22 & 0,23 & 1,00 & 2,73 & 1,2 & 0,72 \\
C23 & 0,20 & 0,37 & 1,00 & 0,50 & 0,36 \\
C24 & 0,28 & 0,83 & 2,00 & 1,00 & 0,58 \\
C25 & 0,61 & 1,39 & 2,78 & 1,72 & 1,00 \\
\hline Toplam & 2,32 & 7,98 & 13,62 & 7,98 & 4,29 \\
\hline
\end{tabular}

Tablo 9' da görüldüğü gibi sistem kalitesine ilişkin matris üzerinde normalizasyon işlemi gerçekleştirilmiştir. Oluşturulan normalize edilmiş matris, özvektörler ve matrise ilişkin tutarlılık göstergeleri Tablo 10’ da verilmiştir.

Tablo 10: Sistem Kalitesi Iç̧in Normalize Edilmiş Matris ve Özvektörler

\begin{tabular}{lcccccc}
\hline & C21 & C22 & C23 & C24 & C25 & Özvektör \\
\hline C21 & 0,431 & 0,550 & 0,375 & 0,446 & 0,380 & 0,437 \\
C22 & 0,098 & 0,125 & 0,200 & 0,150 & 0,168 & 0,148 \\
C23 & 0,084 & 0,046 & 0,073 & 0,063 & 0,084 & 0,070 \\
C24 & 0,121 & 0,104 & 0,147 & 0,125 & 0,135 & 0,127 \\
C25 & 0,265 & 0,174 & 0,204 & 0,216 & 0,233 & 0,218 \\
& & \multicolumn{7}{c}{$\lambda_{\max }=5,06740$} & CR $=0,01504<0,10$ \\
\hline
\end{tabular}

Tablo 10' da yer alan ikili karşılaştırmalara göre en önemli alt kriterin 0,437 ağırlık katsayısı ise güvenlik olduğu ve güvenlik alt kriterini sırasıyla erişim, cevap verme süresi, gezinme kolaylığı ve kişiselleştirme alt kriterlerinin izlediği görülmüştür. Karşılaştırma matrisi 0,01504 tutarlılık oranı ile tutarlı bulunmuştur.

Hizmet kalitesi alt kriterlerinin önem derecelerinin belirlenmesi:

Bu adımda sistem kalitesinin alt kriterleri olan empati, duyarlılık, güvenilirlik, güven alt kriterleri ikili olarak karılaştırılmıştır. İkili karşılaştırmalara ilişkin karar matrisi Tablo 11' de görülmektedir.

Tablo 11: Hizmet Kalitesi Alt Kriterleri İ̧in ikili Karşılaştırma Matrisi

\begin{tabular}{lllll}
\hline & C31 & C32 & C33 & C34 \\
\hline C31 & 1,00 & 0,97 & 0,39 & 0,53 \\
C32 & 1,03 & 1,00 & 0,38 & 0,70 \\
C33 & 2,56 & 2,63 & 1,00 & 1,21 \\
C34 & 1,89 & 1,43 & 0,83 & 1,00 \\
\hline Toplam & 6,48 & 6,03 & 2,60 & 3,44 \\
\hline
\end{tabular}

Tablo 11' de görüldüğü gibi hizmet kalitesine ilişkin matris üzerinde normalizasyon işlemi gerçekleştirilmiştir. Normalizasyon işlemi ile oluşturulan normalize edilmiş matris, özvektörler ve tutarlılık göstergeleri ile birlikte Tablo 12' de görülmektedir. 
Eskişehir Osmangazi Üniversitesi ïBß Dergisi

Tablo 12: Hizmet Kalitesi İçin Normalize Edilmiş Matris ve Özvektörler

\begin{tabular}{cccccc}
\hline & C31 & C32 & C33 & C34 & Özvektör \\
\hline C31 & 0,154 & 0,161 & 0,15 & 0,154 & 0,155 \\
C32 & 0,159 & 0,166 & 0,146 & 0,203 & 0,169 \\
C33 & 0,396 & 0,436 & 0,385 & 0,352 & 0,392 \\
C34 & 0,291 & 0,237 & 0,318 & 0,291 & 0,284 \\
& & & $\lambda_{\max }=4,01597$ & CR $=0,00592<0,10$ \\
\hline
\end{tabular}

Tablo 12' de görüldüğü gibi güvenilirlik alt kriterinin 0,392 önem katsayısı ilk sırada olduğu, güvenilirlik alt kriterini ise sırasıyla güven, duyarlılık ve empati alt kriterlerinin takip ettiği görülmüştür. Karşılaştırma matrisi 0,00592 tutarlılık oranı ile tutarlı kabul edilmiştir.

\subsection{Kriterlere İlişkin Nihai Önem Derecelerinin Belirlenmesi}

Sentez işleminin gerçekleştirildiği bu aşamada öncelikle alt kriterlere ait ağırlıklar, bir üst seviyede bağlı oldukları kriterlerin ağırlıkları ile çarpılmış ve her bir alt kriterin hiyerarşik yapı içerisindeki global (nihai) ağırlıkları elde edilmiştir. Bu işlem sonucundan elde edilen nihai ağırlıklar Tablo 13' de görülmektedir.

Tablo 13: Alt Kriterlerin Nihai Önem Düzeyleri

\begin{tabular}{|c|c|c|c|c|c|}
\hline Temel Kriter & $\begin{array}{l}\text { Temel } \\
\text { Ağırlığı }\end{array}$ & Alt Kriterler & $\begin{array}{c}\text { Alt Kriter } \\
\text { Ağırlığı }\end{array}$ & $\begin{array}{l}\text { Nihai Ağırlık- } \\
\text { lar }\end{array}$ & Siralama \\
\hline \multirow[t]{5}{*}{ C1-Bilgi Kalitesi } & 0,347 & & & & \\
\hline & & C11-ilgili olma & 0,232 & 0,0805 & 9 \\
\hline & & C12-Anlaşılabilirlik & 0,352 & 0,1221 & 2 \\
\hline & & C13-Güncellik & 0,286 & 0,0992 & 5 \\
\hline & & C14-Zenginlik & 0,129 & 0,0448 & 11 \\
\hline \multirow[t]{6}{*}{ C2-Sistem Kalitesi } & 0,273 & & & & \\
\hline & & C21-Güvenlik & 0,437 & 0,1193 & 3 \\
\hline & & $\begin{array}{c}\text { C22-Cevap Verme } \\
\text { Süresi }\end{array}$ & 0,148 & 0,0404 & 12 \\
\hline & & C23-Kişiselleştirme & 0,070 & 0,0191 & 13 \\
\hline & & C24-Gezinme Kolaylığı & 0,127 & 0,0347 & 10 \\
\hline & & C25-Erişim & 0,218 & 0,0595 & 7 \\
\hline \multirow[t]{5}{*}{ C3-Hizmet Kalitesi } & 0,380 & & & & \\
\hline & & C31-Empati & 0,155 & 0,0589 & 8 \\
\hline & & C32-Duyarlılık & 0,169 & 0,0642 & 6 \\
\hline & & C33-Güvenilirlik & 0,392 & 0,1490 & 1 \\
\hline & & C34-Güven & 0,284 & 0,1079 & 4 \\
\hline
\end{tabular}

Çalışma sonucunda, e-hizmet kalitesini etkileyen unsurların önem düzeyleri özetle Şekil $6^{\prime}$ da görülmektedir. 
Şekil 6: Kriterlerin Nihai Önem Düzeyleri

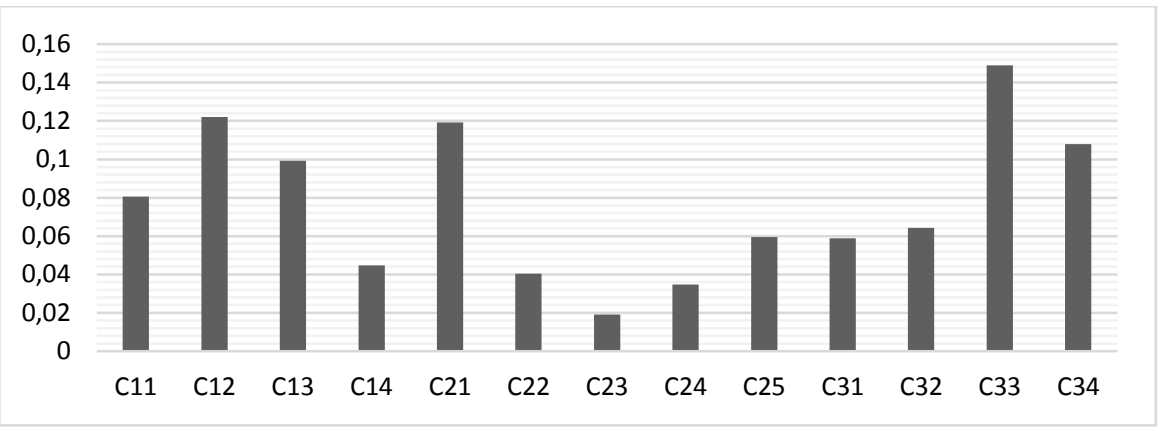

\section{Sonuç}

Bu çalışmada, havayolu işletmelerinde bilgi teknolojilerinin ve e-hizmetlerin yoğun bir şekilde kullanımı ve kalitenin ticari başarı için önemli bir gösterge olması düşüncesinden hareketle, havayolu işletmelerinin sunduğu e-hizmetlerde kaliteyi etkileyen kriterlerin önem düzeyleri değerlendirilmiştir.

Illk olarak e-hizmet kalitesi yaklaşımı baz alınarak literatür taraması yapılmış ve değerlendirme kriterleri belirlenmiştir. Bu kapsamda elde edilen 3 ana kriter ve 13 alt kriter AHP yöntemi yardımıyla analiz edilmiştir. Sonuç olarak havayolu sektöründe e-hizmet kalitesini etkileyen en önemli kriterin hizmet kalitesi (C3) olduğu belirlenmiştir. Bu bulgu literatürde elde edilmiş bulguları destekler niteliktedir (Ustasüleyman, 2013; Alptekin vd., 2015). Hizmet kalitesini ise sırasıyla bilgi kalitesi ve sistem kalitesi kriterleri takip etmiştir. Dolayısıyla, bu bulgular doğrultusunda havayolu taşımacılığı sektöründe sunulan e-hizmetlerde en fazla önemsenen hususların hizmetlerin aksaklık yaşanmadan teslim edilmesi, etkileşimin sorunsuz gerçekleşmesi ve hizmetlere ilişkin sunulan bilginin kalitesi olduğu düşünülmektedir. Diğer yandan hizmet kalitesi ve bilgi kalitesi kriterlerinin öne çıkması Hofstede' in Kültür Boyutlar Teorisi' ne göre bilinmeyen ve aşina olunmayan durumların tehdit olarak algılanması ve rahatsılık yaratmasını ifade eden belirsizlikten kaçınma düzeyinin ülkemizde oldukça yüksek olmasını bir sonucu olarak ele alınabilir (Lim ve diğerleri, 2004: 555; Arpacı, 2015: 703).

Çalışmada alt kriterler içerisinde güvenilirlik (C33), anlaşılabilirlik (C12), güvenlik (C21), güven (C34) ve güncellik (C3) unsurların öne çıktığı görülmüştür. Bu alt kriterlerin literatürde farklı çalışmalarda da ön plana çıktığı görülmektedir (Lee ve Kozar, 2006; Yu, 2010; Chou ve Cheng, 2012; Ustasüleyman, 2013). Bu noktada özellikle artan hava trafiği neticesinde hizmetlerde aksaklıklar yaşanmasının sonucu olarak (gecikme, uçuş iptali ve overbooking 5 vb.) hizmetlerin söz verildiği şekilde yerine getirilmesini ifade eden güvenilirlik alt kriterinin öne çıktığı düşünülmektedir. Diğer yandan havayolu taşımacılığında frekans sıklığının oldukça yüksek olması nedeniyle karmaşıklık yaşanmaması noktasında bilgilerin anlaşılabilirliği ve güncelliği alt kriterlerinin öne çıktığı düşünülmektedir. Güvenlik alt kriteri ise çok sayıda çalışmada öne çıkmakla birlikte (Yu, 2010; Hsu vd., 2012), tüketicilerin kişisel ve kredi kartı bilgilerinin gizliliğinden duyduğu endişenin yüksekliğinin bir göstergesi olarak görülebilir.

Çalışma yönetsel açıdan incelenecek olursa, edinilen bulguların havayolu işletmelerine başarılı e-hizmetlerde öncelenen unsurları anlama ve bu bilgiler ışı̆̆ında daha tatmin edici hiz-

\footnotetext{
${ }^{5}$ Uçakların kapasite fazlası satış yapması overbooking olarak adlandırılmaktadır. Böyle durumlarda kapasite fazlası yolcular biletleri olmasına rağmen ilgili uçuşa kabul edilmemektedir.
} 
met sağlama olanağı sağlayacağı öngörülmektedir. Bu bakımdan çalışmanın hizmet tasarımı sürecinde kulak verilmesi gereken "müşterinin sesi"ni havayollarına başarılı bir şekilde sunduğu söylenebilir. Ayrıca çalışmada güvenilirlik, anlaşılabilirlik ve güvenlik gibi belirsizliğe ilişkin unsurların öne çıktığı görülmektedir. Nitekim Blut ve diğerleri (2015: 679)' de kültür boyutlarının e-hizmet kalitesine yönelik algılar üzerinde düzenleyici etkiye sahip olduğunu bulmuşlardır. Dolayısıyla havayolu yöneticileri açısında hizmet verdikleri ülkelere ilişkin kültürel unsurların web sitesi tasarımında dikkate alınması oldukça yerinde olacaktır.

Havacılık alanında e-hizmet kalitesine yönelik çalışmalarda istatistiksel yaklaşımlara sıklıkla rastlanırken, ÇKKV yöntemiyle ele alınan ve hiyerarşik bir modelin kurulduğu çalışmaların eksikliği nedeniyle çalışmada AHP yöntemi kullanılmıştır. Çalışmada elde edilen bulguların havayolu işletmelerine web sitelerini tasarlarken ilgili unsurlara ağırlık vermeleri noktasında yol gösterebileceği düşünülmektedir. Nitekim gelecek çalışmalar için birtakım öneriler sıralanabilir. Öncelikle odak grup vb. yöntemlerle e-hizmet kalitesini etkileyen farklı kriterlerinde tespit edilmesi ile hiyerarşik model geliştirilebilir. Diğer yandan alanda yapılmış çalışmalar ağırlıklı olarak web siteler üzerine yoğunlaşmasına karşın havayolu taşımacılığı sektöründe mobil cihazlarında yoğun bir şekilde kullanıldığı ve buna dair güçlü bir trend olduğu görülmektedir (SITA, 2016). Dolayısıyla mobil cihazlarda hizmet kalitesi konusu araştırılması elzem ve literatürdeki büyük bir boşluğa sahip bir alan olarak karşımıza çıkmaktadır. Son olarak çalışmada AHP yöntemi kullanılmasına karşın gelecek çalışmalarda farklı ve entegre yöntemlerin kullanımı literatürün zenginleşmesine katkı sağlayacaktır. 


\section{Kaynaklar}

Al-Momani , Khalid; \& Noor, Nor Azila M. (2009), "E-service quality, ease of use, usability and enjoyment as antecedents of e-CRM performance: an empirical investigation in Jordan mobile phone services", The Asian Journal of Technology Management, 2(2), 50-63.

Alptekin, Nesrin, Hall, Elif E.; Sevim, Nurdan (2015) "Evaluation of Websites Quality Using Fuzzy TOPSIS Method", International Journal of Academic Research in Business and Social Sciences, 5(8), 221-242.

Arpacı, İbrahim (2015), "A comparative study of the effects of cultural differences on the adoption of mobile learning", British Journal of Educational Technology, 46(4), 699-712.

Bakır, Mahmut; Atalık, Özlem (2017), "Havayolu İşletmelerinde E-hizmet Kalitesine Yönelik Algıların Demografik Değişkenlere Göre İncelenmesi: Y Kuşağı Üzerine Bir Araştırma", International Journal of Disciplines Economics\& Administrative Sciences Studies, 3(4), 280-293.

Barnes, Stuart J.; Vidgen, Richard (2001), "An Evaluation of Cyber-Bookshops: The WebQual Method", International Journal of Electronic Commerce, 6(1), 11-30.

Blut, Markus; Chowdhry, Nivriti; Mittal, Vikas; Brock, Christian (2015), "E-service quality: A meta-analytic review", Journal of Retailing, 91(4), 679-700.

Chou, Wen-Chin; Cheng, Yi-Ping (2012), "A hybrid fuzzy MCDM approach for evaluating website: quality of professional accounting firms", Expert Systems with Applications, 39(3), 2783-2793.

Çelik, Hakan; Başaran, Bülent (2008), "Bireysel müşteriler tarafından algılanan elektronik hizmet kalitesi", Anadolu Üniversitesi Sosyal Bilimler Dergisi, 8(2), 129-152.

Çelik, Pelin; Gök Kısa, Ayşe C. (2017), "Fuzzy AHP-Fuzzy PROMETHEE Approach in Evaluation of E-service Quality: Case of Airline Web Sites", Uluslararası Sosyal Araştırmalar Dergisi, 10(52), 1003-1013.

Dominic, P. D.D.; Khan, Humera (2014), "Performance Measure of Airline Websites Using Analytical Hierarchy Process\& Fuzzy Analytical Hierarchy Process", International Conference on Control System, Computing and Engineering (s. 530-535), Penang: IEEE.

Ecer, Fatih (2014), "A hybrid banking websites quality evaluation model using AHP and COPRAS-G: a Turkey case", Technological and Economic Development of Economy, 20(4), 758-782.

Golden, William; Higgins, Eoin; Hughes, Martin; Flynn, Susan (2003), "The Internet, a creator of electronic markets for airline tickets", Collaborative Electronic Commerce Technology and Research(CoLLECTeR), (s. 204-213). Galway, Ireland.

Güreş, Nuriye; Arslan, Seda; Yılmaz , Harun (2015), "E-service Quality, Passenger Satisfaction and Passenger Loyalty Relationship in Airline Industry", Journal of Management, Marketing and Logistics, 2(1), 44-56.

Hsu, Tsuen-Ho; Hung, Li-Chu; Tang, Jia-Wei (2012), "A hybrid ANP evaluation model for electronic service quality", Applied Soft Computing, 12(1), 72-81.

Jati, Handaru (2009), "Performance Evaluation on Quality of Asian Airlines Websites- An AHP Approach", 4th International Conference on E-Commerce with focus on Developing Countries (s. 1-10). Kuala Lumpur: ECDC Conference.

Jun, Minjoon; Cai, Shaohan (2001), "The key determinants of internet banking service quality: a content analysis", International Journal of Bank Marketing, 19(7), 276-291.

Kaynama, Shohreh A.; Black, Christine I. (2000), "A proposal to assess the service quality of online travel agencies: An exploratory study", Journal of professional services marketing, 21(1), 63-88.

Kecek, Gülnur; Yıldırım, Esra (2010), "Kurumsal kaynak planlama (ERP) sisteminin analitik hiyerarşi süreci (AHP) ile seçimi: otomotiv sektöründe bir uygulama", Süleyman Demirel Üniversitesi íktisadi ve İdar iBilimler Fakültesi Dergisi, 15(1), 193-211.

Kotler, Philip; Keller, Kevin L. (2012), Marketing Management (14 b.), Prentice Hall.

Kuruüzüm, Ayşe; Atsan, Nuray (2001), "Analitik Hiyerarşi Yöntemi ve İşletmecilik Alanındaki Uygulamaları", Akdeniz Üniversitesi İktisadi ve İdari Bilimleri Fakültesi, 1(1), 83-105.

Kwiesielewicz, Miroslaw; Van Uden, Ewa (2004), "Inconsistent and contraditory judgements in pairwise comparison method in the AHP", Computer\& Operations Research, 31(5), 713-719.

Lau, Teck-Chai; Kwek, Choon-Ling; Tan, Hoi-Piew (2011), "Airline e-ticketing service: How e-service quality and customer satisfaction impacted purchase intention", International Business Management, 5(4), 200-2008. 


\section{Eskişehir Osmangazi Üniversitesi IïB Dergisi}

Lee, Feng-Hui; Wu, Wann-Yih (2011), "Moderating effects of technology acceptance perspectives on e-service quality formation: Evidence from airline websites in Taiwan", Expert Systems with Applications, 38(6), 7766-7773.

Lee, Younghwa; Kozar, Kenneth A. (2006), "Investigating the effect of website quality on e-business success: An analytic hierarchy process (AHP) approach", Decision Support Systems, 42(2006), 1383-1401.

Lim, Kai H.; Leung, Kwok; Sia, Choon L.; Lee, Matthew K. (2004), "Is eCommerce boundary-less? Effects of individualism-collectivism and uncertainty avoidance on Internet shopping", Journal of International Business Studies, 35(6), 545-559.

Lin, Hsiu-Fen (2010),"An application of fuzzy AHP for evaluating course website quality" Computers\& Education, 54(4), 877-888.

Loiacono, Eleanor T.; Watson, Richard T.; Goodhue, Dale L. (2002), "WebQual: A measure of website quality", Marketing Theory and Applications, 13(3), 432-438.

Long, Mary; McMellon, Charles (2004), "Exploring the determinants of retail service quality on the internet", Journal of Services Marketing, 18(1), 78-90.

Madu, Christian N.; Madu, Assumpta A. (2002), "Dimensions of e-quality", International Journal of Quality\& Reliability Management, 19(3), 246-258.

Majid, Muhammad K.; Bakri, Norhani; Md Arif, Mohd S. (2015), "Electronic service quality of Malaysia airline industries(low cost carrier)", Journal of Advanced Research Design, 11(1), 11-22.

Marangoz, Mehmet (2014), Internette Pazarlama, İstanbul: Beta Basım Yayım Dağıım.

Nilashi, Mehrbakhsh; Bagherifard, Karamollah; Ibrahim, Othman; Janahmadi, Nasim; Ebrahimi, Leila (2012), "Ranking parameters on quality of online shopping websites using multi-criteria method", Research Journal of Applied Sciences, Engineering and Technology, 4(21), 4380-4396.

Ömürbek, Nuri; Şimşek, Ali (2012), "Üniversite öğrencilerinin cep telefonu tercihlerinin Analitik Hiyerarşi Prosesi ile belirlenmesi", Niğde Üniversitesi İktisadi ve İdari Bilimler Fakültesi Dergisi, 5(1), 116-32.

Parasuraman, A.; Zeithaml, Valarie A., \& Malhotra, Arvind (2005), "E-S-QUAL: A multiple-item scale for assessing electronic service quality", Journal of Service Research, 7(3), 213-233.

Rowley, Jennifer (2006), "An analysis of the e-service literature: towards a research agenda", Internet Research, 16(3), 339-359.

Saaty, Thomas L. (1990), "How to make a decision: the analytic hierarchy process", European Journal of Operational Research, 48(1), 9-26.

Sam, Mohd Fazlı M.; Tahir, Md Nor H. (2009), "Web Site Quality and Consumer Online Purchase Intention of Air Ticket", International Journal of Basic\&Applied Sciences, 9(10), 20-25.

Santos, Jessica (2003), "E-service quality: a model of virtual service quality dimensions", Managing Service Quality: An International Journal, 13(3), 233-246.

Sarıçalı, Gizem; Kundakçı, Nilsen (2016), "AHP ve COPRAS yöntemleri ile otel alternatiflerinin değerlendirilmesi", International Review of Economics and Management, 4(1), 45-66.

Shaw, Stephen (2007), Airline marketing and management (6. b.), Hampshire: Ashgate Publishing Limited.

Shchiglik, Clarry; Barnes, Stuart J. (2004), "Evaluating website quality in the airline industry", Journal of Computer Information Systems, 44(3), 17-25.

Sismanidou, Athina; Palacios, Miguel; Tafur, Javier (2009), "Progress in airline distribution systems: The threat of new entrants to incumbent players", Journal of industrial engineering and management, 2(1), 251-272.

SITA. (2016), "PASSENGERS IT TRENDS SURVEY", http://www.sita.aero/resources/type/surveys-reports/passenger-ittrends-survey-2016, (Erişim: 18.08.2017).

Supçiller, Aliye A.; Çapraz, Ozan (2011), "AHP-TOPSIS Yöntemine Dayali Tedarikçi Seçimi Uygulaması", İstanbul Üniversitesi İktisat Fakültesi Ekonometri ve İstatistik Dergisi(13), 1-22.

Thakran, Kanika; Verma, Rohit (2013), "The emergence of hybrid online distribution channels in travel, tourism and hospitality", Cornell Hospitality Quarterly, 54(3), 240-247.

Tsai, Wen-Hsien; Chou, Wen-Chin; Lai, Chien-Wen (2010), "An effective evaluation model and improvement analysis for national park websites: A case study of Taiwan", Tourism Management, 31(6), 936-952.

Tsai, Wen-Hsien; Chou, Wen-Chin; Leu, Jun-Der (2011), "An effectiveness evaluation model for the web-based marketingof the airline industry", Expert Systems with Application, 38, 15499-15516. 
Tütek, Hülya H.; Gümüşoğlu, Şevkinaz; Özdemir, Aslı (2012), Sayısal yöntemler: yönetsel yaklaşım (6. b.), İstanbul: Beta Basım Yayın.

Ustasüleyman, Talha (2013), "Bankacılık sektöründe internet sitesi kalitesi boyutlarının (kriterlerinin) önem derecesinin belirlenmesi", CBÜ Sosyal Bilimler Dergisi, 11(1), 146-162.

Vatansever, Kemal; Akgül, Yakup (2014), "Applying fuzzy analytic hierarchy process for evaluating service quality of private shopping website quality: A case study in Turkey", Journal of Business Economics and Finance, 3(3), 283301.

Vatansever, Kemal; Akgül, Yakup (2018), Performance evaluation of websites using entropy and grey relational analysis methods: The case of airline companies", Decision Science Letters, 7, 119-130.

Wensveen, J. G. (2007), Air Transportation : A Management Perspective (6. b.), Hampshire: Ashgate Publishing Limited.

Wind, Yoram; Saaty, Thomas L. (1980), "Marketing Applications of the Analytic Hierarchy Process", Management Science, 26(7), 641-658.

Wolfinbarger, Mary; Gilly, Mary C. (2003), "eTailQ: dimensionalizing, measuring and predicting etail quality", Journal of Retailing, 79(3), 183-198.

Xie, Zhou C.; Barnes, Stuart J. (2008), "Web Site Quality in The UK Airline Industry: A Longitudinal Examination", Journal of Computer Information Systems, 49(2), 50-57.

Yoo, Boonghee; Donthu, Naveen (2001), "Developing a scale to measure the perceived quality of an Internet shopping site (SITEQUAL)", Quarterly Journal of Electronic Commerce, 2(1), 31-45.

Yu, Yanggang (2010), "Evaluation of E-commerce service quality using the analytic hierarchy process", International Conferences on and Information Technology\& Ocean Engineering (s. 123-126), IEEE. 
Eskişehir Osmangazi Üniversitesi IißBF Dergisi 